\title{
PENGARUH TINGKAT PENGETAHUAN, SIKAP DAN KETERAMPILAN PENERAPAN SISTEM AGRIBISNIS TERHADAP PRODUKSI PADA PETANI PADI DI KECAMATAN CIMANGGU KABUPATEN CILACAP
}

\section{(The effect of knowledges, attitudes and skills in the application of tithout the agribusiness system on the production of rice farmers at Cimanggu Subdistrict, Cilacap Regency)}

\author{
M. L. Fadhilah., B. T. Eddy dan S. Gayatri \\ Program Studi S1 Agribisnis Fakultas Peternakan dan Pertanian \\ Universitas Diponegoro, Kampus Tembalang - Semarang 50275 \\ Email :flutfi70@gmail.com
}

Diterima 16 September 2017, disetujui 20 Februari 2018

\begin{abstract}
ABSTRAK
Tujuan dari penelitian ini untuk 1) mengukur tingkat produksi padi pada petani, 2) mengukur tingkat pengetahuan, sikap dan keterampilan dalam penerapan sistem agribisnis pada petani padi, 3) menganalisis pengaruh tingkat pengetahuan, sikap dan keterampilan penerapan sistem agribisnis terhadap produksi. Penelitian dilaksanakan pada 25 Januari sampai 28 Februari 2017 di Kecamatan Cimanggu, Kabupaten Cilacap. Metode yang digunakan dalam penelitian ini adalah survei dengan jumlah responden 100 orang. Teknik pengumpulan data menggunakan kuesioner, wawancara, dan observasi sedangkan teknik analisis data menggunakan analisis deskriptif dan analisis regresi linier ganda. Hasil penelitian menunjukkan bahwa 1). produksi padi sebesar 6,71 ton/ha, 2) tingkat pengetahuan, sikap dan keterampilan petani masuk dalam kriteria tinggi, 3) variabel pengetahuan, sikap, dan keterampilan berpengaruh nyata secara bersama-sama maupun secara parsial terhadap produksi.
\end{abstract}

Kata Kunci: keterampilan, padi, pengetahuan, produksi, sikap.

\section{ABSTRACT}

The aims of the study were to 1) measure the level of rice production of the farmers 2) measure the level of knowledges, attitudes and skills in the application of agribusiness system, 3 ) analyze the influence of knowledge, attitudes and skills of applying agribusiness system to production. The research was conducted on 25 January 2017 to 28 February 2017 in the Subdistrict Cimanggu, Cilacap Regency. Methods used in this research was a survey method with 100 respondents. The data were collected using questionnaires, interviews, and observations while the data analysis techniques using descriptive analysis and multiple linear regression analysis. The research results showed that 1) rice production of $6,71 \mathrm{ha} / \mathrm{ton}, 2)$ the knowledge, attitudes and skill farmers are inhigh criteria, 3) knowledge variable, attitude, and skill had a significant influence both in simultaneously and partially on the rice production. Keywords: knowledges, attitudes, skills, production, rice.

\section{PENDAHULUAN}

Seiring bertambahnya penduduk Indonesia semakin banyak pula kebutuhan akan pangan. Padi merupakan komoditas utama pangan Indonesia karena mayoritas penduduk Indonesia mengkonsumsi beras 
sebagai pangan utama. Jumlah penduduk Indonesia pada tahun 2016 sebanyak 258.705.000 jiwa. Kenaikan penduduk tiap tahun sekitar $1,38 \%$. Menurut perkiraan melalui pendekatan historis, jumlah penduduk Indonesia pada tahun 2035 diperkirakan mencapai 300.107.580 jiwa. Di lihat produksi padi nasional sebanyak 75,39 juta ton (Badan Pusat Statistik, 2017).

Peran petani sangat vital karena petani merupakan aktor utama penghasil beras. Petani padi sebagai penghasil beras harus mendapat perhatian baik mengenai lahan, benih, teknologi dan cara budidaya maupun pasca panen (Manyamsari dan Mujiburrahmad, 2014). Keberhasilan usaha tani sangat tergantung kepada kompetensi petani sebagai pengelola utama. Kompetensi petani tidak sama satu dengan lainnya, hal ini sangat tergantung kepada karakteristik yang mereka miliki. Kompetensi petani dapat ditingkatkan melalui penyuluhan. Penyuluh pertanian merupakan agen bagi perubahan perilaku petani, yaitu mendorong petani mengubah perilakunya menjadi petani dengan kemampuan yang lebih baik dan mampu mengambil keputusan sendiri, yang selanjutnya akan memperoleh kehidupan yang lebih baik (Setiana, 2005).

Sistem agribisnis yang ada sebenarnya baik jika diterapkan secara komprehensif oleh petani karena akan meningkatkan produtivitas dan pendapatan petani. Sistem agribisnis sebagai suatu konsep yang menempatkan kegiatan pertanian sebagai suatu kegiatan yang utuh dan komprehensif sekaligus sebagai suatu konsep yang dapat menelaah dan menjawab berbagai masalah dan tantangan (Pradina et al., 2007). Agribisnis terdiri dari beberapa subsistem, diantaranya adalah subsistem hulu, subsistem proses usahatani, subsistem hilir dan subsistem penunjang (Firdaus, 2009). Berjalannya sistem agribisnis secara merata disetiap petani, maka proses usahatani terhadap suatu komoditas dapat dipastikan berjalan dengan baik dan meningkatkan efisiensi serta efektivitas produksi. Penerapan sistem agribisnis diperlukan perilaku petani yang dapat mendukung berjalannya sistem agribisnis yang baik. Perilaku petani terdiri dari elemen pengetahuan, sikap dan keterampilan yang membentuk karakter (Gerungan, 2004). Ketiga elemen itu yang menjadikan dasar dapat terwujudnya sistem agribisnis.

Tujuan dari penelitian ini adalah 1). Mengukur tingkat produksi padi pada petani 2). Mengukur tingkat pengetahuan, sikap dan keterampilan penerapan sistem agribisnis 3). Menganalisis pengaruh tingkat pengetahuan, sikap dan keterampilan penerapan sistem agribisnis terhadap produksi di Kecamatan Cimanggu Kabupaten Cilacap. Manfaat yang dapat diambil dari penelitian ini, antara lain dapat dijadikan bahan pertimbangan bagi stakeholder dalam upaya meningkatkan produksi padi dan kualitas petani.

\section{METODE PENELITIAN}

\section{Kerangka Pemikiran}

Berdasarkan latar belakang masalah diperoleh kerangka pemikiran pada Ilustrasi 1.

Penelitian ini menggunakan metode survei. Metode survei merupakan metode penelitian yang dilakukan untuk mengadakan pemeriksaan dan pengukuran-pengukuran terhadap gejala empiris yang berlangsung di lapangan atau lokasi penelitian umumnya dilakukan terhadap unit sampel yang dihadapi sabagai responden dan bukan terhadap seluruh populasi sasaran (Fatoni, 2006).

Penelitian ini dilaksanakan pada 25 Januari sampai 28 Februari 2017. Lokasi penelitian ditetapkan secara purposive yaitu di Desa Cisalak dan Desa Cilempuyang, Kecamatan Cimanggu, Kabupaten Cilacap. Kedua desa terpilih karena memiliki kriteria yang dibutuhkan yaitu untuk lokasi kecamatan memiliki dataran rendah dan perbukitan serta memiliki jumlah petani terbanyak di Kabupaten Cilacap.

Pengumpulan data penelitian ini menggunakan kuesioner terstruktur yang diisi dengan wawancara untuk mendapatkan informasi yang berkaitan dengan tingkat pengetahuan, sikap dan keterampilan 


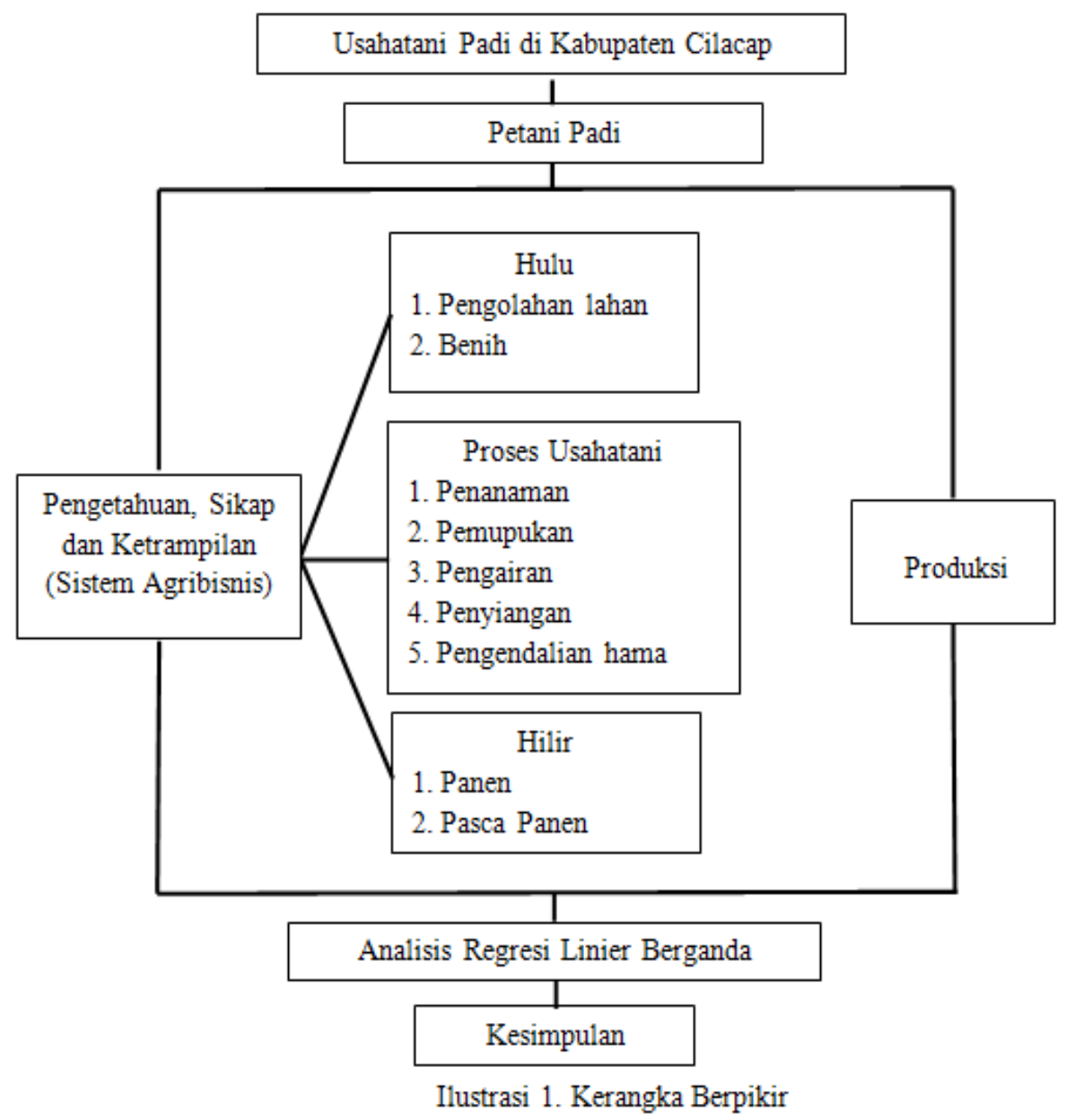

penerapan sistem agribisnis dan produksi. Data sekunder pendukung diperoleh dari kelompok tani, Kantor Kecamatan Cimanggu, Kantor Desa Cilempuyang dan Cisalak.

Pengambilan sampel ditentukan dengan metode nonprobabilitas (metode quota sampling), yaitu teknik untuk menentukan sampel dari populasi yang mempunyai ciriciri tertentu sampai jumlah (kuota) yang diinginkan (Sugiyono, 2008). Petani sampel adalah petani yang memiliki luas lahan $\leq 2$ ha sebanyak 100 responden atau tiap desa ditetapkan berjumlah 50 responden.

Data yang diperoleh di lapangan diolah tabulasi kemudian dianalisis secara deskriptif, yaitu dengan memaparkan hasil yang didapat dalam bentuk uraian yang sistematis sehingga diperoleh hasil yang lengkap dan terperinci. Pengolahan data untuk tujuan mengukur tingkat pengetahuan, sikap dan keterampilan dalam penerapan sistem agribisnis pada petani padi digunakan pengukuran dengan menggunakan metode skor. Pemberian skor untuk setiap item indikator, dengan skor 1 sampai 5, dan dapat dilihat dengan menggunakan pembagian interval kelas. Menggunakan rumus Rambe dan Honorita (2011), maka dapat ditentukan interval kelas untuk masing-masing indikator, dengan ketentuan :
1. NR $=\mathrm{NST}-\mathrm{NSR}$
2. PI $=$ NR : JIK

Keterangan :

NR = Nilai Range

NST = Nilai Skor Tertinggi

NSR $=$ Nilai Skor Terendah

PI $=$ Panjang Interval

JIK = Jumlah Interval Kelas

Terdapat 3 variabel (X) (pengetahuan, sikap, keterampilan) dalam penelitian ini dan setiap variabel (X) memiliki 9 indikator (pengolahan lahan, benih, penanaman, 
pemupukan, pengairan, penyiangan, pengendalian hama, panen, pascapanen) serta setiap indikator terdapat 5 pertanyaan dengan menggunakan skala likert untuk variabel sikap, skala bogardus untuk variabel pengetahuan dan keterampilan sehingga total terdapat 135 pertanyaan. Perhitungan untuk membuat interval kelas pada tiap indikator perilaku petani dalam berusahatani padi di Kecamatan Cimanggu Kabupaten Cilacap, yaitu:

\section{Perhitungan:}

Nilai range (NR) didapatkan dari hasil pengurangan nilai skor tertinggi (NST) dikurangi nilai skor terendah (NSR). Nilai skor tertinggi (NST) sebesar 25 dan nilai skor terendah (NSR) sebesar 5 maka nilai range (NR) sebesar 20. Panjang interval (PI) didapatkan dari hasil pembagian antara nilai range (NR) dengan jumlah interval kelas (JIK). Nilai range (NR) sebesar 20 dan jumlah interval kelas (JIK) sebesar 3 maka panjang interval sebesar 6,66.

Perhitungan per-item indikator:

Nilai range (NR) didapatkan dari hasil pengurangan nilai skor tertinggi (NST) dikurangi nilai skor terendah (NSR). Nilai skor tertinggi (NST) sebesar 5 dan nilai skor terendah (NSR) sebesar 1 maka nilai range (NR) sebesar 4. Panjang interval (PI) didapatkan dari hasil pembagian antara nilai range (NR) dengan jumlah interval kelas

(JIK). Nilai range (NR) sebesar 4 dan jumlah interval kelas (JIK) sebesar 3 maka panjang interval sebesar 1,33.

Setelah mendapat kriteria penentuan setiap indikator tahap selanjutnya menentukan kriteria tiap variabel. Penentuan kriteria variabel didapatkan berdasarkan hasil tiap tiap indikator. Perhitungan untuk membuat interval kelas pada tiap indikator perilaku petani untuk mengukur masing-

Tabel 1. Nilai Interval Kelas Skor Total, Interval Kelas Per Pertanyaan Seluruh Sub Sistem Agribisnis

\begin{tabular}{cccc}
\hline No. & $\begin{array}{c}\text { Nilai Interval Kelas } \\
(\text { Skor Total) }\end{array}$ & $\begin{array}{c}\text { Interval Kelas } \\
(\text { Per Pertanyaan })\end{array}$ & Kriteria Nilai \\
\hline 1. & $5,00<\mathrm{x} \leq 11,66$ & $1,00<\mathrm{x} \leq 2,33$ & Rendah \\
2. & $11,67<\mathrm{x} \leq 18,33$ & $2,34<\mathrm{x} \leq 3,66$ & Sedang \\
3. & $18,34<\mathrm{x} \leq 25,00$ & $3,67<\mathrm{x} \leq 5,00$ & Tinggi \\
\hline
\end{tabular}

Tabel 2. Nilai Indikator Perilaku Petani untuk Komponen (Pengetahuan, Sikap, dan Keterampilan)

\begin{tabular}{llccccc}
\hline No & \multicolumn{1}{c}{ Sistem Agribisnis } & NST & NSR & JIK & NR & PI \\
\hline 1 Pengolahan Lahan & 225 & 45 & 3 & 180 & 60 \\
2 & Benih & 225 & 45 & 3 & 180 & 60 \\
3 & Penanaman & 225 & 45 & 3 & 180 & 60 \\
4 & Pemupukan & 225 & 45 & 3 & 180 & 60 \\
5 & Pengairan & 225 & 45 & 3 & 180 & 60 \\
6 & Penyiangan & 225 & 45 & 3 & 180 & 60 \\
7 & Pengendalian Hama dan Penyakit & 225 & 45 & 3 & 180 & 60 \\
8 & Panen & 225 & 45 & 3 & 180 & 60 \\
9 & Pascapanen & 225 & 45 & 3 & 180 & 60 \\
\hline
\end{tabular}


masing komponen perilaku petani pada Tabel 2.

Perhitungan:

Nilai range (NR) didapatkan dari hasil pengurangan nilai skor tertinggi (NST) dikurangi nilai skor terendah (NSR). Nilai skor tertinggi (NST) sebesar 225 dan nilai skor terendah (NSR) sebesar 45 maka nilai range (NR) sebesar 180. Panjang interval (PI) didapatkan dari hasil pembagian antara nilai range (NR) dengan jumlah interval kelas (JIK). Nilai range (NR) sebesar 180 dan jumlah interval kelas (JIK) sebesar 3 maka panjang interval sebesar 60 .

Perhitungan per-item indikator :

Nilai range (NR) didapatkan dari hasil pengurangan nilai skor tertinggi (NST) dikurangi nilai skor terendah (NSR). Nilai skor tertinggi (NST) sebesar 5 dan nilai skor terendah (NSR) sebesar 1 maka nilai range (NR) sebesar 4. Panjang interval (PI) didapatkan dari hasil pembagian antara nilai range (NR) dengan jumlah interval kelas (JIK). Nilai range (NR) sebesar 4 dan jumlah interval kelas (JIK) sebesar 3 maka panjang interval sebesar 1,33.

Analisis data untuk tujuan menganalisis pengaruh tingkat pengetahuan, sikap dan keterampilan terhadap produksi meggunakan regresi linier berganda. Setelah data memenuhi asumsi klasik maka data selanjutnya dianalisis mengunakan model regresi linier berganda Penghitungan menggunakan rumus regresi linear berganda yaitu ( Ghozali, 2011):

$\mathrm{Y}=\mathrm{a}+\mathrm{b}_{1} \mathrm{X}_{1}+\mathrm{b}_{2} \mathrm{X}_{2}+\mathrm{b}_{3} \mathrm{X}_{3}+\mathrm{e}$

Keterangan:

$\mathrm{Y}=$ Produksi (Ton)

a $=$ Nilai konstanta $\mathrm{b}=$ Nilai koefisien regresi

$\mathrm{e}=$ Error

$\mathrm{X}_{1}=$ Tingkat Pengetahuan (skor, $1=$ Tidak dapat menjawab, 2= Menjawab 1 jawaban, 3= Menjawab 2 jawaban, 4= Menjawab 3 jawaban, 5= Menjawab 4 jawaban, dengan menggunakan skala bogardus)

$\mathrm{X}_{2}=$ Tingkat Sikap (skor, $1=$ Sangat Tidak Setuju, 2 = Tidak Setuju, 3 = Ragu-Ragu, $4=$ Setuju, $5=$ Sangat Setuju, dengan menggunakan skala Likert)

$\mathrm{X}_{3}=$ Tingkat Ketrampilan (skor, $1=$ Tidak dapat menjawab, 2 = Menjawab 1 jawaban, 3 = Menjawab 2 jawaban, 4= Menjawab 3 jawaban, 5= Menjawab 4 jawaban, dengan menggunakan skala Bogardus)

Uji $F$ digunakan untuk mengetahui pengaruh variabel independen dengan dependen secara serempak. Hipotesis statistik yang diambil sebagai berikut :

$$
\begin{aligned}
& H_{0}: b_{1}=b_{2}=b_{3}=b 4=0 \\
& H_{i}: b_{1} \neq b 2 \neq b 3 \neq b 4 \neq 0
\end{aligned}
$$

$\mathrm{H}_{0}=$ Tidak ada pengaruh dari variabel independen terhadap variabel dependen.

$\mathrm{H}_{\mathrm{i}} \quad=$ Ada pengaruh dari variabel independen terhadap variabel dependen untuk minimal satu variabel independen.

Kriteria pengambilan keputusan yaitu :

$\mathrm{H}_{0}$ ditolak dan $\mathrm{H}_{\mathrm{i}}$ diterima jika $\operatorname{sig}_{\text {hit }} \leq 0,05$.

$\mathrm{H}_{\mathrm{i}}$ ditolak dan $\mathrm{H}_{0}$ diterima jika sig $\mathrm{ghit}_{\text {hit }}>0,05$.

Uji $t$ digunakan untuk mengetahui besarnya pengaruh variabel independen dan dependen secara parsial. Hipotesis statistik yang diambil adalah sebagai berikut

$$
\begin{aligned}
& H_{0}: b_{1}=0 ; b_{2}=0 ; b_{3}=0 ; b 4=0 \\
& H_{i}: b_{1} \neq 0 ; b 2 \neq 0 ; b 3 \neq 0 ; b 4 \neq 0
\end{aligned}
$$

$\mathrm{H}_{0}=$ Tidak ada pengaruh dari variabel independen ke $\mathrm{n}$ terhadap variabel dependen.

Tabel 3. Nilai Interval Kelas Skor Total, Interval Kelas Per Pertanyaan, dan Kriteria Nilai Masing-Masing Perilaku (Pengetahuan, Sikap dan Keterampilan) Petani

\begin{tabular}{cccc}
\hline No. & $\begin{array}{c}\text { Nilai Interval Kelas } \\
(\text { Skor Total) }\end{array}$ & $\begin{array}{c}\text { Interval Kelas } \\
(\text { Per Pertanyaan })\end{array}$ & Kriteria Nilai \\
\hline 1. & $45,00<\mathrm{x} \leq 105,00$ & $1,00<\mathrm{x} \leq 2,33$ & Rendah \\
2. & $106,00<\mathrm{x} \leq 165,00$ & $2,34<\mathrm{x} \leq 3,66$ & Sedang \\
3. & $166,00<\mathrm{x} \leq 225,00$ & $3,67<\mathrm{x} \leq 5,00$ & Tinggi \\
\hline
\end{tabular}


$\mathrm{H}_{\mathrm{i}}=$ Ada pengaruh dari variabel independen ke $\mathrm{n}$ terhadap variabel dependen.

Kriteria pengambilan keputusan yaitu :

$\mathrm{H}_{0}$ ditolak dan $\mathrm{H}_{\mathrm{i}}$ diterima jika sig $\operatorname{sit}_{\text {hit }} \leq 0,05$. $\mathrm{H}_{\mathrm{i}}$ ditolak dan $\mathrm{H}_{0}$ diterima jika sig hit $_{\text {hit }}>0,05$.

\section{HASIL DAN PEMBAHASAN}

\section{Identitas Responden}

Responden pada penelitian ini adalah petani. Identitas responden ditentukan berdasarkan usia, tingkat pendidikan dan pengalaman bertani. Identitas responden dapat dilihat pada Tabel 4. Identitas responden didaerah penelitian menunjukkan bahwa paling banyak responden berusia antara 41-50 tahun sebanyak 38 orang (38\%). Petani responden rata-rata masih dalam usia produktif, sehingga kesempatan untuk menyerap informasi dan inovasi lebih besar. Hal ini sesuai pendapat Wibowo (2002) yang menyatakan bahwa usia produktif manusia berada pada kisaran umur 14 - 55 tahun.

Berdasarkan Tabel 4 terlihat bahwa responden paling banyak berpendidikan SD yaitu sebanyak 56 orang (56\%). Tingkat pendidikan atau ilmu sesorang dapat mempengaruhi cara berpikir untuk lebih mengembangkan dan meningkatkan hasil pertanian kearah yang lebih baik. Kusnadi (2005) berpendapat bahwa pendidikan dapat mempertahankan stabilitas, kontinuitas dan mendorong untuk masa depan yang lebih baik Pengalaman bertani pada Tabel 4 Pengalaman bertani menunjukan bahwa paling banyak antara 11-15 tahun sebanyak 30 orang (30\%). Petani responden rata-rata memiliki pengalaman bertani padi sudah cukup lama. Lama pengalaman bertani membuat petani memiliki pengetahuan dan keterampilan usaha tani padi yang tinggi pula. Hal ini sesuai dengan hasil penelitian Istiantoro (2013) yang berisi pengalaman bertani dan pendidikan non formal berpengaruh signifikan terhadap tingkat penerapan sistem pertanian berkelanjutan pada budidaya padi sawah.

\section{Tingkat Produksi Padi}

Berdasarkan hasil penelitian didapatkan produksi padi di daerah penelitian sebesar

Tabel 4. Jumlah dan Persentase Karakteristik Responden

\begin{tabular}{|c|c|c|c|c|}
\hline $\mathrm{No}$ & Karakteristik & Pengukuran & Jumlah & Persentase \\
\hline \multirow{7}{*}{1} & \multirow{6}{*}{ Usia } & & -------petani------ & ---------\%o--------- \\
\hline & & $20-30$ & 3 & 3 \\
\hline & & $31-40$ & 28 & 28 \\
\hline & & $41-50$ & 38 & 38 \\
\hline & & $51-60$ & 16 & 16 \\
\hline & & $61-70$ & 15 & 15 \\
\hline & TOTAL & & 100 & 100 \\
\hline \multirow{4}{*}{2} & \multirow{4}{*}{ Pendidikan } & $\mathrm{SD} / \mathrm{M} 1$ & 56 & 56 \\
\hline & & SMP/MTs & 25 & 25 \\
\hline & & SMA/MA & 17 & 17 \\
\hline & & D3/S1 & 2 & 2 \\
\hline \multirow{7}{*}{3} & TOTAL & & 100 & 100 \\
\hline & \multirow{5}{*}{ Pengalaman Bertani } & $1-5$ & 3 & 3 \\
\hline & & $6-10$ & 20 & 20 \\
\hline & & $11-15$ & 30 & 30 \\
\hline & & $16-20$ & 22 & 22 \\
\hline & & $>20$ & 25 & 25 \\
\hline & TOTAL & & 100 & 100 \\
\hline
\end{tabular}


6,71 ton. Hasil tersebut lebih tinggi dibandingkan dengan produktivitas Kecamatan Cimanggu secara keseluruhan. Pada Tahun 2015 produktivitas 6,368 ton/ha (Badan Pusat Statistika, 2015). Tingkat produksi padi di Kecamatan Cimanggu Kabupaten Cilacap dipengaruhi varietas padi yang digunakan yaitu varietas muncul. Hal ini sesuai dengan pendapat Balai Besar Penelitian Tanaman Padi (2009) yang menyatakan bahwa varietas padi mucul memiliki rata-rata hasil panen sebesar 6 ton/ha dengan potensi hasil sebesar 7 ton/ha.

\section{Tingkat Pengetahuan Petani}

Pengetahuan petani dalam usahatani padi di Kecamatan Cimanggu Kabupaten Cilacap diukur dari pengolahan lahan, pemilihan benih, penanaman benih, pemupukan, pengairan, penyiangan, pengendalian hama dan penyakit, panen dan pascapanen. Pengukuran komponen pengetahuan petani contoh dapat dilihat pada Tabel 5.

Tingkat pengetahuan petani padi dalam penerapan sistem agribisnis di Kecamatan Cimanggu Kabupaten Cilacap termasuk dalam kriteria tinggi. Faktor-faktor yang mempengaruhi pengetahuan secara umum antara lain pendidikan, sosial budaya, ekonomi, lingkungan, pengalaman, dan usia. Hal ini sesuai dengan pendapat yang menyatakan (Rambe dan Honorita, 2011) bahwa pengetahuan dipengaruhi oleh pengalaman, lama bertani dan lingkungan petani. Adanya pengetahuan yang baik tentang suatu hal, akan mendorong terjadinya perubahan perilaku pada diri individu, dimana pengetahuan tentang manfaat suatu hal akan menyebabkan seseorang bersikap positif terhadap hal tersebut, demikian pula sebaliknya.

\section{Tingkat Sikap Petani}

Berdasarkan hasil penelitian didapatkan tingkat sikap petani di Kecamatan Cimanggu Kabupaten Cilacap adalah sebagai berikut:

Tabel 6. Kriteria dan Rata-Rata Sikap Petani dalam Usahatani Padi di Kecamatan Cimanggu Kabupaten Cilacap

\begin{tabular}{llcc}
\hline No & Sistem Agribisnis & $\begin{array}{c}\text { Skor } \\
\text { rata-rata }\end{array}$ & Kriteria \\
\hline 1 & Pengolahan Lahan & 20,95 & Tinggi \\
2 & Benih & 21,15 & Tinggi \\
3 & Penanaman & 21,19 & Tinggi \\
4 & Pemupukan & 21,36 & Tinggi \\
5 & Pengairan & 21,24 & Tinggi \\
6 & Penyiangan & 20,44 & Tinggi \\
7 & Pegendalian Hama & 20,56 & Tinggi \\
& dan Penyakit & & \\
8 & Panen & 20,67 & Tinggi \\
9 & Pasca Panen & 20,77 & Tinggi \\
& Jumlah & 188,33 & Tinggi \\
\hline
\end{tabular}

Sumber: Data primer yang diolah, 2017.

Tabel 5. Kriteria dan Rata-Rata Pengetahuan Petani dalam Usahatani Padi di Kecamatan Cimanggu Kabupaten Cilacap

\begin{tabular}{clcc}
\hline No & \multicolumn{1}{c}{ Sistem Agribisnis } & Skor rata-rata & Kriteria \\
\hline 1. & Pengolahan Lahan & 20,66 & Tinggi \\
2. & Benih & 20,59 & Tinggi \\
3. & Penanaman & 20,28 & Tinggi \\
4. & Pemupukan & 21,11 & Tinggi \\
5. & Pengairan & 20,58 & Tinggi \\
6. & Penyiangan & 21,18 & Tinggi \\
7. & Pengendalian Hama dan Penyakit & 21,34 & Tinggi \\
8. & Panen & 20,95 & Tinggi \\
9. & Pascapanen Jumlah & 20,32 & Tinggi \\
& & 187,01 & Tinggi \\
\hline
\end{tabular}


Pengukuran komponen sikap petani dapat dilihat pada Tabel 6. Tingkat sikap petani padi dalam penerapan sistem agribisnis di Kecamatan Cimanggu Kabupaten Cilacap termasuk dalam kriteria tinggi yang berarti bahwa petani terbuka untuk setiap informasi, inovasi, program-program, dan anjuran pemerintah dalam kegiatan usahatani padi. Hal ini dapat dilihat dari sikap petani yang setuju dari setiap indikator pertanyaan yang diajukan. Sikap tidak akan memberi respon secara langsung terhadap suatu perubahan, menyadari bahwa pengetahuan dan sikap dipengaruhi oleh pengalaman (Rambe dan Honorita, 2011). Purwanto (2005) mengatakan pengalaman juga dapat membentuk sikap sebagai proses semakin meningkatnya pengetahuan yang dimiliki petani termasuk didalamnya pengalaman penggunaan teknologi baru. Pengetahuan merupakan tahap awal terjadinya persepsi yang kemudian melahirkan sikap dan pada gilirannya melahirkan perbuatan atau tindakan. Pengalaman menunjukkan bahwa interaksi yang terjadi cenderung mengakibatkan adanya diri yang timbal balik serta penyesuaian kecakapan dengan situasi baru.

\section{Tingkat Keterampilan Petani}

Berdasarkan hasil penelitian didapatkan tingkat keterampilan petani di Kecamatan Cimanggu Kabupaten Cilacap adalah sebagai berikut:

Pengukuran komponen keterampilan petani dapat dilihat pada Tabel 7. Tingkat keterampilan petani padi dalam penerapan sistem agribisnis di Kecamatan Cimanggu Kabupaten Cilacap termasuk dalam kriteria tinggi. Keterampilan dapat dilihat dari kemampuan petani dalam melakukan kegiatan bertani yang bersifat fisik. Namun yang menjadi dasar petani melakukan pekarjaan secara fisik adalah kemampuan petani dalam menentukan keputusan yang diambil sehingga kemampuan yang ada dapat digunakan secara maksimal sehingga petani keterampilan yang tinggi. Faktor-faktor yang mempengaruhi keterampilan antara lain pengalaman dan usia. Usia petani mayoritas pada usia produktif yaitu 41-50 tahun begitu pula pengalaman bertani yang kebanyakan lebih dari 10 tahun. Usia petani adalah salah satu faktor yang berkaitan erat dengan kemampuan kerja dalam melaksanakan kegiatan usahatani, usia dapat dijadikan sebagai tolak ukur dalam melihat aktivitas

Tabel 7. Kriteria dan Rata-Rata Keterampilan Petani dalam Usahatani padi di Kecamatan Cimanggu Kabupaten Cilacap

\begin{tabular}{|c|c|c|c|}
\hline No & Sistem Agribisnis & Skor rata-rata & Kriteria \\
\hline 1 & Pengolahan Lahan & 20,92 & Tinggi \\
\hline 2 & Benih & 20,89 & Tinggi \\
\hline 3 & Penanaman & 20,70 & Tinggi \\
\hline 4 & Pemupukan & 21,08 & Tinggi \\
\hline 5 & Pengairan & 20,77 & Tinggi \\
\hline 6 & Penyiangan & 21,10 & Tinggi \\
\hline 7 & Pegendalian Hama dan Penyakit & 20,71 & Tinggi \\
\hline 8 & Panen & 20,83 & Tinggi \\
\hline 9 & Pasca Panen & 20,68 & Tinggi \\
\hline & Jumlah & 187,68 & Tinggi \\
\hline
\end{tabular}

Sumber: Data primer yang diolah, 2017. 
seseorang dalam bekerja dimana dengan kondisi usia yang masih produktif maka kemungkinan besar seseorang dapat bekerja dengan baik dan maksimal (Hasyim, 2006).

\section{Pengaruh Tingkat Pengetahuan, Sikap dan Keterampilan Terhadap Produksi}

Berdasar hasil analisis regresi linier ganda diperoleh model sebagai berikut: $\mathrm{Y}=-5,192+0,024 \mathrm{X}_{1}+0,021 \mathrm{X}_{2}+0,021 \mathrm{X}_{3}$

Berdasarkan hasil analisis regresi linier berganda diperoleh hasil dalam Tabel 8 .

Berdasarkan Tabel 8 diketahui pengaruh tingkat pengetahuan, sikap, dan keterampilan penerapan sistem agribisnis terhadap produksi padi di Kecamatan Cimanggu Kabupaten Cilacap.

Nilai koefisien determinasi $\left(\mathrm{R}^{2}\right)$ sebesar 0,201 atau 20,1\%, artinya tingkat pengetahuan, sikap, dan keterampilan penerapan sistem agribisnis mempengaruhi produksi padi sebesar $20,1 \%$ sedangkan sisanya sebesar $79,9 \%$ produksi padi dipengaruhi oleh variabel lain yang tidak diteliti dalam penelitian ini. Ghozali (2011) menyatakan bahwa tujuan analisis regresi adalah mencari nilai estimasi koefisien regresi dan menarik inferensi statistik sehingga tinggi rendahnya nilai $\mathrm{R}^{2}$ tidak bermasalah. Jika dalam proses analisis mendapatkan $\mathrm{R}^{2}$ tinggi adalah baik, nilai $\mathrm{R}^{2}$ rendah bukan berarti model regresi tersebut tidak baik.

Berdasarkan analisis uji $\mathrm{F}$ diperoleh hasil nilai signifikansi sebesar 0,000 . Nilai signifikansi $<0,01$ sehingga hasil tersebut menunjukkan bahwa tingkat pengetahuan, sikap, dan keterampilan penerapan sistem agribisnis secara serempak berpengaruh nyata terhadap produksi padi. Akumulasi sikap atau persepsi, pengetahuan dan keterampilan akan menentukan perilaku seseorang. Besar kecil perilaku petani yang dilihat dari aspek pengetahuan, sikap dan keterampilan ini akan mempengaruhi proses penerapan sistem agribisnis sehingga berdampak pada produksi. Pengetahuan merupakan tahap awal dari persepsi yang kemudian mempengaruhi sikap dan pada tahap selanjutnya melahirkan perbuatan atau tindakan (keterampilan). Adanya wawasan petani yang baik tentang suatu hal, akan mendorong terjadinya sikap yang pada gilirannnya mendorong terjadinya perubahan perilaku. Petani memiliki keterampilan yang baik dapat menentukan pilihannya dengan tepat sehingga dapat mengetahui hal efesien dan efektif (Rambe dan Honorita, 2011).

Hasil uji secara parsial pengetahuan berpengaruh terhadap produksi padi. Semakin tinggi pengetahuan penerapan sistem agribisnis maka semakin tinggi produksi padi. Sebaliknya, semakin rendah pengetahuan penerapan sistem agribisnis maka semakin rendah produksi padi. Peningkatan produksi dapat terjadi jika adopsi inovasi yang diakukan petani berjalan dengan baik. Petani yang memiliki pengetahuan yang banyak akan memberikan suatu pilihan terbaik dalam menentukan suatu keputusan karena pengetahuan menjadi elemen dasar bagi petani dalam adopsi inovasi. Hal ini sesuai

Tabel 8. Hasil Regresi Linier Ganda

\begin{tabular}{|c|c|c|c|c|c|}
\hline No & Variabel bebas & Koefisien Regresi & Nilai $\mathrm{t}$ & Sig. & Keterangan* \\
\hline 1 & Pengetahuan $\left(\mathrm{X}_{1}\right)$ & 0,024 & 2,061 & 0,042 & Signifikan \\
\hline 2 & Sikap $\left(\mathrm{X}_{2}\right)$ & 0,021 & 2,143 & 0,027 & Signifikan \\
\hline 3 & Keterampilan $\left(\mathrm{X}_{3}\right)$ & 0,021 & 2,041 & 0,044 & Signifikan \\
\hline & Variabel terikat & \multicolumn{4}{|l|}{ : Produksi } \\
\hline & Konstanta & \multicolumn{4}{|l|}{$:-5,192$} \\
\hline & $\mathrm{R}$ square $\left(\mathrm{R}^{2}\right)$ & \multicolumn{4}{|l|}{$: 0,201$} \\
\hline & F hitung & \multicolumn{4}{|l|}{$: 8,041$} \\
\hline & Sig. & \multicolumn{4}{|l|}{$: 0,000$} \\
\hline
\end{tabular}

Keterangan: *) Sig. pada $\alpha 5 \%$ 
pendapat Welson et al. (2011) yang menyatakan bahwa pengetahuan menjadi dasar sebuah adopsi dapat dilakukan dengan baik atau tidak. Hal tersebut diperkuat oleh pendapat Sormin (2012) yang menyatakan bahwa pengetahuan merupakan salah satu komponen perilaku petani yang turut menjadi faktor dalam adopsi inovasi.

Hasil uji secara parsial sikap berpengaruh terhadap produksi padi. Semakin tinggi sikap penerapan sistem agribisnis maka semakin tinggi produksi padi. Tinggi tingkat sikap mengindikasi kecenderungan petani dalam menerima inovasi akan membuat lebih efektifnya suatu adopsi. Hal ini sesuai pendapat Gerungan (2004) yang menyatakan bahwa sikap yang terbuka akan suatu inovasi akan memudahkan dalam penerapan inovasi tersebut. Hal tersebut diperkuat oleh pendapat Sarwono (2005) yang menyatakan bahwa sikap positif akan terjadi apabila terdapat suatu kecendrungan untuk menerima perilaku yang dianjurkan, dan sebaliknya sikap negatif terjadi jika terdapat kecenderungan yang menolak terhadap suatu objek tertentu.

Hasil uji secara parsial keterampilan berpengaruh terhadap produksi padi. Semakin tinggi keterampilan penerapan sistem agribisnis maka semakin tinggi produksi padi. Sebaliknya, semakin rendah keterampilan penerapan sistem agribisnis maka semakin rendah produksi padi. Tinggi tingkat keterampilan akan membuat meningkatnya efektifitas dan efisiensi. Hal ini sesuai pendapat Padmowihardjo (2000) yang menyatakan bahwa keterampilan petani merupakan proses komunikasi pengetahuan untuk mengubah perilaku petani menjadi efektif, efisien dan cepat melalui pengembangan teknologi.

\section{SIMPULAN DAN SARAN}

Hasil penelitian menunjukkan bahwa 1) Produksi padi sebesar 6,71 ton/ha, 2) pengetahuan, sikap dan keterampilan petani padi dalam penerapan sistem agribisnis di Kecamatan Cimanggu Kabupaten Cilacap memiliki kriteria tinggi, 3) Pengetahuan, sikap, dan keterampilan berpengaruh nyata secara serempak maupun secara parsial. Hal ini berarti semakin tinggi pengetahuan, sikap dan keterampilan petani padi dalam penerapan sistem agribisnis maka semakin tinggi produksi padi di Kecamatan Cimanggu Kabupaten Cilacap.

Bagi pemerintah diharapkan dapat memberikan inovasi dan teknologi yang tepat untuk petani untuk meningkatkan produksi padi yang berujung pada peningkatan kesejahteraan dengan dengan memperhatikan kondisi. Bagi petani diharapkan dapat terus belajar meningkatkan pengetahuan dan keterampilan dalam bertani dengan mengikuti perkemangan teknologi yang ada sehingga dapat meningkatkan kesejahteraan

\section{DAFTAR PUSTAKA}

Badan Pusat Statistik. 2015. Luas Panen, Produksi, dan Produktivitas Padi Sawah di Kabupaten Cilacap tahun 2015. Berita Resmi Statistik, Cilacap.

Badan Pusat Statistik. 2017. Statistik Indonesia 2017. Berita Resmi Statistik, Jakarta.

Balai Besar Penelitian Tanaman Padi. 2009. Pengairan beselang. Badan Penelitian dan Pengembangan Pertanian. Departemen Pertanian.

Fatoni, A. 2006. Metodologi Penelitian dan Teknik Penyusunan Skripsi. PT Rineka Cipta. Jakarta.

Firdaus, M. 2009. Manajemen Agribisnis. Bumi Aksara, Jakarta.

Ghozali, I. 2011. Aplikasi Analisis Multivariate Dengan Program SPSS. Badan Penerbit. Universitas Diponegoro, Semarang.

Gerungan, W. A. 2004. Psikologi Sosial. Edisi Tiga. Refika Aditama, Bandung.

Ghozali, I. 2011. Aplikasi Analisis Multivariate Dengan Program SPSS. Badan Penerbit. Universitas Diponegoro, Semarang.

Hasyim, H. 2006. Produksi Benih. FP-USU Press, Medan.

Istiantoro. 2013. Tingkat penerapan sistem pertanian berkelanjutan pada budidaya padi sawah (studi kasus di kecamatan 
ambal kabupaten kebumen). Prosiding Seminar Nasional Pengelolaan Sumberdaya Alam dan Lingkungan. 5 (2) : 19-25

Kusnadi, D. 2005. Kepemimpinan Kontaktani dalam Meningkatkan Efektifitas Kelompok Tani. Institut Pertanian Bogor. Bogor.

Manyamsari, I dan Mujiburrahmad. 2014. Karakteristik petani dan hubungannya dengan kompetensi petani lahan sempit. Jurnal Agrisep. 2 (15) : 1-25

Padmowihardjo, S., 2000. Metode Penyuluhan Pertanian. Universitas Terbuka, Jakarta.

Pradina, W., D. Sulistya dan A. Setiawati. 2007. Pengembangan agribisnis padi sawah melalui pemberdayaan kelompok tani. Jurnal Penyuluhan Pertanian. 2 (2): 171-182

Purwanto. 2005. Tujuan pendidikan dan hasil belajar. Jurnal Teknodik Depdiknas. Jakarta.

Rambe, S. S. M., dan B. Honorita. 2011. Perilaku petani dalam usahatani di lahan rawa lebak. Prosiding Seminar Nasional Budidaya Pertanian 2 (1) : 115-128.

Sarwono, S. W. 2005. Teori-Teori Psikologi Sosial. Rajawali Pers, Jakarta.

Setiana, L. 2005. Pengertian Dasar Penyuluhan Pertanian. Gramedia, Jakarta.

Sormin, E. U. 2012. Analisis tingkat pengetahuan petani terhadap manfaat lahan padi sawah di Kabupaten Sedang Bedagai. Journal Social Economic of Agriculture and Agribusiness. 1 (1) : 114

Sugiyono. 2008. Metode Penelitian Kuantitatif, Kualitatif dan R\&D. Alfabeta. Bandung

Welson, M.W., B.O.L. Suzana dan H.A. Siagian. 2011. Penerapan teknologi usahatani padi sawah. ASE. 7 (1) : 5357

Wibowo, S. 2002. Diktat Pengembangan Wilayah Pedesaan. Sekolah Tinggi Penyuluhan Pertanian Bogor. Bogor. 